\title{
Reign of Terror on the Tibetan Plateau Reading Woeser's Forbidden Memory
}

Tibet During the Cultural Revolution

Yu Jie

\section{OpenEdition}

\section{Journals}

Electronic version

URL: http://journals.openedition.org/chinaperspectives/3463

DOI: 10.4000/chinaperspectives.3463

ISSN: 1996-4617

\section{Publisher}

Centre d'étude français sur la Chine contemporaine

Printed version

Date of publication: 1 January 2008

Number of pages: 104-108

ISSN: 2070-3449

\section{Electronic reference}

Yu Jie, «Reign of Terror on the Tibetan Plateau Reading Woeser's Forbidden Memory », China Perspectives [Online], 2008/1 | 2008, Online since 01 January 2011, connection on 22 September 2020. URL : http://journals.openedition.org/chinaperspectives/3463 ; DOI : https://doi.org/10.4000/ chinaperspectives.3463 
C

Reign of Terror on the

\title{
Tibetan Plateau
}

\author{
Reading Woeser's Forbidden Memory: \\ Tibet During the Cultural Revolution
}

YU IIE

0 everal years ago, I wrote a book review entitled "Apologies to Tibet" in response to Fire Under the Snow, the autobiography of a Tibetan monk, Palden Gyatso, who had been imprisoned for more than 30 years. ${ }^{(1)}$ In this book review I expressed my heart-felt apologies as an ethnic Han intellectual for the half century of devastation and humiliation inflicted on Tibet by the Chinese Communist authorities. After the article was posted, I was subjected to many shrill accusations by China's "angry youth." While I was on a visit to Los Angeles, several overseas students referring to themselves as alumni of Peking University castigated me for "violating national unity." They said my article was completely unacceptable, that I had been hoodwinked by the "Dalai Lama separatist clique," that I had overlooked the backwardness and ignorance of old Tibet under the rule of the lamas and nobility and the bleakness of its slavery, and that I had disregarded the modern civilization that the Communist Party had brought to Tibet. What astonished me most was that their views were indistinguishable from those of People's Daily and the Xinhua News Agency. Even though they had been living in the U.S. and enjoying free access to information, their thinking remained mired in the education and propaganda of their past. This phenomenon revealed the enormous effectiveness of official brainwashing tactics. Among the Chinese people with whom I have had contact, as many as nine out of ten view the Tibet issue in this way. Under the rubric of "national unity" and "modern civilization," the authorities have managed to cover up their reign of terror 50 years ago on the Tibetan plateau, and obliterate it from the memory of China's people.

The Tibetan writer Woeser was born in Tibetan during the violence of the Cultural Revolution. After graduating from college, she served as editor of Tibetan Literature magazine. In her writings she has insisted on depicting Tibet's actual history and reality. As a result, her works have been suppressed many times, and ultimately she lost her job and be- came a freelance writer. Woeser has also been deprived of her civil right to be issued with a passport, and has never been able to travel abroad. This is the price paid by an intellectual who dares to speak the truth; whether the writer is of the Han majority or a member of an ethnic minority, choosing to speak the truth will result in the authorities labelling him or her as a "hostile element." Woeser, whose delicate appearance belies her inner strength, has adopted the ideal of "writing as my travel, my prayer, my witness." Her powerful book Forbidden Memory: Tibet During the Cultural Revolution, published in Taiwan, is the first book to examine the history of the Cultural Revolution in the $\mathrm{Ti}_{\mathrm{i}}$ betan region.

Forbidden Memory is first of all a collection of photographs. Most of the photos in the book were taken by

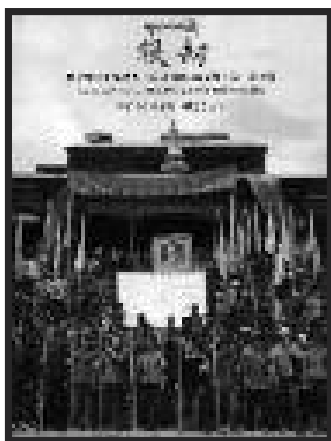

Woeser (Wei Se), Sha jie. Sishi nian de jiyi jinqu. Jingtou xia de Xizang wenhua. Di yi ci gongkai. Forbidden memory. Tibet during the Cultural

\section{Revolution,}

Taipei, Dakuai

wenhua, 2006,

$296 \mathrm{pp}$.
Woeser's father, who was conscripted into the People's Liberation Army at the age of 13, transferred to Lhasa from Kangba, and eventually was promoted to officer rank. Woeser does not make mention in her book of her father's political inclinations or sense of ethnicity, but behind this valuable group of photographs lies a subtle sense of this $\mathrm{T}_{\mathrm{i}}$ -

1. Yu Jie, "Xiang Xizang chanhui: Du 'Xueshan xiade huoyan: yige Xizang liangxinfan de zhengyan' (Apologies to Tibet: Reading 'Fire under the snow-capped mountain: The testament of a Tibetan prisoner of conscience)," originally published in Dongxiang Magazine (Hong Kong), June 2004, accessible on the Boxun Web site: http://www.peacehall.com/news/gb/pubvp/2004/06/200406252141.shtml (last accessed 26 March 2008). Palden Gyatso's book was published in English as Fire Under the Snow, London, Harvill Press, 1997. 


\section{Yu Jie, Woeser, Wang Lixiong}

Yu Jie, born in 1973 in Chengdu, won fame as an acerbic essayist in the late 1990s. A Beijing University graduate and self-declared Lu Xun imitator, he was dismissed from his first assignment at the China Modern Literature Museum in 2000 and chose to live by writing. He has championed various causes, including the US invasion of Iraq, religious freedom in China (after he converted to Chirstianity), and reconciliation with Japan, pointing out that before the current authorities' dispute with Japan over past history, Mao had hailed the Japanese invasion as a means of weakening Chiang Kai-shek, and that far from honouring Nationalist Anti-Japanese fighters, the People's Republic persecuted them as traitors. Yu Jie concluded that, "a sign of maturity of a people is its ability to have sufficient confidence to forgive." (1) Woeser, a Tibetan writing in Chinese, was relieved of her duties at the Tibetan Writers Association in 2003 after she published Notes on Tibet (Xizang biji), a collection of essays on the region's culture. She lives in Beijing with Wang Lixiong, whom she met while he was researching his book Sky Burial (Tianzang). Wang Lixiong, born in 1953, who became famous with his novel Yellow Peril (Huanghuo) in 1991, has also for long been an advocate of Tibetan and Uighur cultures, as well as gradual democratisation in China. Moreover, he has taken up environmental causes, starting an NGO for that purpose as far back as in 1994. ${ }^{(2)}$ Yu and Wang contributed to the 12-point proposals of Chinese intellectuals for resolving the Tibet conflict in March 2008. (S.V.)

\section{- Translated by N. Jayaram}

1. See Yu Jie, "The Anti-Japanese Resistance War, Chinese Patriotism and Free Speech. How Can we Forgive Japan ?", Japan Focus, http://www.japanfocus.org/products/details/2654 (24 April 2008).

2. See Rémi Quesnel, "Wang Lixiong, an atypical intellectual”, China Perspectives, n 50, Nov.-Dec. 2003, p. 57.

betan military officer's confusion and doubt regarding his own identity: when Tibetan historical and cultural heritage sites such as the Jokhang Temple were destroyed, when Tibet's educated class was ruthlessly abused and eliminated, when the Tibetan faith of generations and the gentle Tibetan people were inveigled by class struggle doctrine into becoming victims of mutual annihilation, this Tibetan army officer could not openly protest, but faithfully trained his camera lens to record it all and leave the photographs as history's witness. Perhaps it never occurred to him that his daughter Woeser would become the excavator, compiler, and interpreter of this legacy. If there is awareness among the dead, this father must be smiling in his grave. These hundreds of photos, published for the first time, declare with indisputable authenticity exactly what kind of "civilization" the Chinese Communist government brought to Tibet.

The Cultural Revolution has become a specialised field of academic study in the international arena. For a very long time, a heavily romanticised image of the revolution deceived people more successfully than attempts to cover up the ruthless bloodshed of Stalin's reign in the Soviet Union. During the last half of the twentieth century, most Western intellectuals were aware of the nature of the Gulag Archipel- ago, yet maintained a wishful self-delusion toward Maoism. Now the true picture of the Cultural Revolution has been gradually revealed, and even though some people still express pride at having been among those Mao described as China's "rising sun," the unprecedented anti-cultural nature of the Cultural Revolution is becoming common knowledge. Cultural Revolution research has been gradually expanding over many areas, but a large gap remains in respect of the effect on Tibet. Heavily veiled in mystery, the events that took place at that time on the snow-covered plateau are known to very few outsiders. The scholar Song Yongyi, who has spent many years researching the Cultural Revolution, once said to Woeser, "We are sorely lacking in information about Tibet... We really know much too little about the Cultural Revolution in Tibet!" For that reason, Woeser's Forbidden Memory can be considered the first meaningful attempt to fill that gap.

Through the direct perception and power of photographs, coupled with detailed interviews and in-depth analysis, Forbidden Memory reveals how the Chinese government transformed the secluded Buddhist state into a hell on earth. In these photographs we see temples demolished, cultural artefacts smashed, monks, nuns, and nobles humiliated and 
beaten. We see formidable processions of troops and mountains bedecked with red flags and banners, as well as PLA drills and exercises as the Cultural Revolution makes Tibet increasingly resemble China's inland regions. Throughout the centuries, Tibet had maintained a social structure, culture, and belief system independent of China. After Communist China occupied Tibet through armed force, its class struggle theory began to transform Tibetan society. This transformation had already progressed with reasonable success in the decade or so before the Cultural Revolution, and as a result, the Cultural Revolution's push into Tibet was similar to that in other provinces of China, encountering virtually no resistance. Interpreting photographs of merciless denunciations of "ox devils and snake demons," Woeser makes this observation:

It is obvious that two completely opposite social divisions had emerged to replace the relationships that had existed in the past. Previously, although there had been rich and poor, all shared the same ethnicity; and although there were clergy and lay people, all shared the same religion. But now the division between the two classes was not only clearly delineated, but for the first time in Tibet's history, the lower class was facing the upper class, especially the Living Buddhas and eminent monks who had always been regarded as "treasures," with upraised fists and angry howls. Why was this happening?

How did this violent revolution come to sweep across Tibet? Why did Buddhism fail to serve as a protective screen against violence? Why was Mao Zedong able to become the "Red Sun" of the Tibetan people? On this, Wang Lixiong provides an analysis in his book, Sky Burial: The Fate of Tibet:

Because it had no class struggle, traditional Tibetan society had coalesced into an entity united by religion and ethnicity... In order to split up Tibetan society and capture the allegiance of lower class Tibetans, the Chinese Communists had to raise up another banner by launching class struggle among the Tibetans themselves. Class struggle was the Communists's specialty. If the world were divided into classes, then the unity of Tibet's people and religion could be destroyed. ${ }^{(2)}$

Mao Zedong thus ingeniously changed an ethnic issue into a class issue, and supported by violence, the "spiritual atomic bomb" of Mao Zedong Thought wreaked its havoc on the Buddhist faith that had existed and taken root in Tibet for nearly a thousand years. Naturally, this violent intrusion could only be temporary. Once Maoist fanaticism ebbed and crumbled a little more than ten years later, Buddhism resumed its place as the spiritual bond of Tibetan society. Among the millions of Tibetans today, those who ardently worship the Dalai Lama certainly vastly outnumber those who love Mao.

The secret to the success of Mao's tactic of class struggle was in making atrocities a form of group behaviour that absolved individual participants of culpability. Princeton University Professor of Psychology Susan Fiske, after analysing 25,000 psychological studies, concluded that in the right social context, anyone is capable of committing torture and other "acts of great evil." (3) Particularly worthy of our gratitude and admiration is Woeser's refusal to be constrained by concerns of "face"; she does not whitewash the actions of Tibetans themselves during the Cultural Revolution, nor does she simplistically place wholesale blame on the Han "invaders." Facing historical truth solemnly and sincerely, she does not skirt around the ill conduct of many Tibetans in various political movements, including the Cultural Revolution. She candidly informs the reader that "onlookers" and "participants" also existed among the Tibetans.

In this book's many photographs, the hustling and jostling Tibetan "onlookers" are the spitting image of those Lu Xun wrote about. Woeser writes:

Among the many onlookers that encircled the city, we have no way of knowing how many came to celebrate liberation, how many came out of fear or apprehension, and how many came to serve their personal interests. But one thing we do know is that slaves remained slaves. When their new masters emerged smiling, when the venues previously used to spread Buddhist doctrine became courts of injustice, when an individual was subjected to a humiliating trial on trumped-up charges, those elders and children, men and women among the onlookers may not have qualified as accessories to the crime, but at the very least their superficially docile acceptance revealed that that they remained slaves. The truth was that they had never been truly liberated.

2. Wang Lixiong, Tianzang: Xizang de mingyun (Sky Burial: The Fate of Tibet), Hong Kong, Mirror Books, 1998.

3. Gaia Vince, "Everyone is a potential torturer," New Scientist, 25 November 2004, http://www.newscientist.com/channel/opinion/dn6727-everyone-is-a-potential-torturer.html (last accessed 26 March 2008). 
This analysis goes to the heart of the matter: those immersed "onlookers" were, in Lu Xun's words, "enslaved in spirit."

The phenomenon of the "onlooker" is not specific to any nation or culture; it is common to all human societies. $\mathrm{Hu}$ manity has a cruel instinct to take pleasure in the suffering of others - it is enormously comforting to discover that someone else's situation is worse than one's own. It is this selfish and cruel nature that allows human beings to deceive themselves that they are acting out of "self-preservation." The American scholar Roy F. Baumeister in his book Evil: Inside Human Violence and Cruelty ${ }^{(4)}$ observes that human beings actually enjoy seeing other people suffer or die, that fascination with violence seems to transcend time and culture, and that inflicting injury on others may be a means of enabling oneself to enjoy the well-verified pleasure of seeing the suffering of others with one's own eyes. The Chinese of the Mao era, regardless of whether they were of the Han, Tibetan or other ethnicity, all became caught up in this evil. Mao was simply the person who let the genie out of the bottle, and we cannot shift the sole blame on him; each and every one of us bears an unshirkable responsibility.

The so-called "participants" were those "special Tibetans" who abetted the evil-doers. Among these, the majority originally belonged to the lower classes, with a minority consisting of "traitors" from the upper classes. Without their help, it would have been impossible for the Chinese government to so successfully extend its policies and movements into Tibet. Without their cooperation, it would have been impossible for the Chinese government to so effectively consolidate its rule of Tibet over the past half a century. In many instances, these collaborators behaved even more harshly than the ruling outsiders in order to demonstrating their loyalty. Woeser points out:

As early as 1950, the Chinese government deployed troops to Tibet, and while promising to establish a "dazzling New Tibet" it simultaneously applied itself to spiritual brainwashing and material inducements. This attracted the following of many lower-class $T_{i-}$ betans, as well as hot-blooded youths from the upper classes. It can even be said that China's ability to establish a "mass base" in Tibet was the result of its "brainwashing" education through the repeated instilling of terms such as "exploitation" and "oppression" and the negation of the Buddhist concepts of the "next life" and karma.
Like Jews who acted as overseers of concentration camps for the Nazis, these "participants," even though categorized as members of an inferior race, did not hesitate to betray their fellows for the sake of improving their own chances of survival.

The evil that revealed itself in these people is the most deepseated evil of humanity. It is not specific to any race, nor is any race completely immune to it. I have never subscribed to the overly mythologized depiction of the "spotless incorruptibility" of the snowy plateau and the Tibetan people who exist on it. Tibet was never Shangri-La or the Garden of Eden, neither of which exist anywhere on this earth. We must accept this as fact: there is nothing easier to induce or call forth than evil, either among the Han or among the Tibetans. Among the many evil acts of the Cultural Revolution, those committed by Tibetans were no better than those committed by Han Chinese.

Taken from a broader perspective, we are obliged to acknowledge that during the cruel political movements of the Mao era, the acts committed by Chinese of all stripes within China's borders were no better than those of Germans under the Nazis or Russians during the Stalin era. Long-standing religious beliefs may also be eroded by violence and viciousness; as the Nazis rose to power, most Catholic and Protestant clergy cast their votes for Hitler and took oaths of loyalty to him, and Christians and intellectuals such as Dietrich Bonhoeffer who stood up in resistance were few and far between. Likewise, in the Tibet of the Mao era, many Tibetans put their faith "on hold" or renounced it altogether. This is the weakness of human nature. Although human civilization has been developing over thousands of years, its accumulated veneer remains as thin and fragile as window paper; without systemic protections, and relying only on the human conscience, it cannot withstand the onslaught of evil.

While courageously denouncing the Chinese government's invasion of Tibet and the damage it wreaked, Woeser also reflects deeply on the ethnic character and cultural traditions of Tibet. The self-examination that Woeser undertakes as a Tibetan herself is especially valuable at a time when the whole world regards Tibet with a hyper-romanticized Orientalism. Woeser interviewed most of the people who appear in the photographs, including individuals currently holding senior positions in Tibet's government hierarchy, as well as those who were used by the authorities and then cast aside to spend their last years in desolate loneliness. Regardless of social position or whether they were "onlookers" or "partici-

4. Roy F. Baumeister, Evil: Inside Human Violence and Cruelty, New York, Macmillan, 1996. 
pants," the large majority refuse to repent of what they did during the Cultural Revolution; only a minority have quietly returned to the embrace of Buddhism to seek spiritual peace. Woeser discovered that the impassioned youths photographed brandishing whips and fists have for the most part become enfeebled and apathetic. In them she finds a "banality of evil" similar in nature, if not in cause, to that discovered by the anti-totalitarian philosopher Hannah Arendt. ${ }^{(5)}$ In the person of Adolf Eichmann, the "Angel of Death" of the Nazi concentration camps, Arendt found not a devil in human guise, but an ordinary person, so ordinary, in fact, as to be deeply disappointing. Upon confronting a notorious murderer who kills other human beings like flies, you would expect to feel a frisson of horror, and might even fear to sit near him or allow him to cast his eyes on you. Yet this man's face and bearing looked like someone with whom you had ridden on a public bus any number of times, someone you would hardly notice or recall. The people Woeser writes about in her book are for the most part just this sort of person. They killed others, yet their ignorance, obstinacy, and banality strike one as ridiculous rather than horrifying. This is the real world we live in: "they" live undistinguishable among "us."

Forbidden Memory is an unusual book composed of photographs, interviews, history, reflections, inquiries, and searching. The page must finally be turned on this historical episode of carnage. More people must join in the exceptional work that Woeser has undertaken.

\section{- Translated by Stacy Mosher}

